\title{
Analytical mathematical model of the pumping unit of machine water lifting systems
}

\author{
K. G. Abidov ${ }^{1, *}$, Sh.O. Zaripova ${ }^{2}$, N.B.Khamudkhanova ${ }^{1}$, S.A.Dusmukhamedova ${ }^{1}$, M.O.Gafurova ${ }^{1}$, H.Baratov ${ }^{1}$ \\ ${ }^{1}$ Tashkent State Technical University named after Islam Karimov University street №2, Tashkent city; Uzbekistan \\ ${ }^{2}$ Karshi Institute of Engineering and Economics
}

\begin{abstract}
The article discusses the formation of a mathematical model of a pumping unit of a machine water lifting system to ensure energy-saving modes of operation as a criterion for assessing the effectiveness of its operation, it is necessary to take the minimum specific consumption of electrical energy for water supply with appropriate restrictions imposed on the conditions of its operation.
\end{abstract}

\section{Introduction}

The main technical and economic indicators of the pumping unit, as well as the entire pumping station are efficiency of the pumping unit (station) and the specific power consumption spent on the pumping water into the pressure network [2].

The authors determined that when forming a mathematical model of a pumping unit of the machine water lifting system in order to ensure energy-saving modes of operation assessing the, it is necessary to take the minimum specific consumption of electrical energy for water flow with appropriate restrictions imposed on the conditions of its operation as a criterion effectiveness of its operation.

Due to the fact that in the overwhelming majority of pumping stations are operated by pumping units consisting of a group of pumping units structurally united for joint work in a common pressure pipeline, we will initially determine the specific power consumption of the pumping unit.

\section{Materials and research methods}

Due to the fact that in the overwhelming majority of pumping stations are operated by pumping units consisting of a group of pumping units structurally united for joint work in a common pressure pipeline, we will initially determine the specific power consumption of the pumping unit.

As is known [3,4], the specific power consumption for the supply of 1 million $\mathrm{m}^{3}$ of pumped water to a height of 1 meter of water column for a pumping unit is determined by the following expression:

$\Delta \ni=2,724 / \eta_{H A . i}, \mathrm{~kW} * \mathrm{~h} / 1 \mathrm{mln} . \mathrm{m}^{3} \cdot \mathrm{m}$,

where

$\eta_{H A . i}=\eta_{i} \cdot \eta_{д B . i} \cdot \eta_{\Pi . i} \cdot$
Here is the efficiency. the i-th pumping unit as part of the pumping system;

- efficiency pump of the i-th pump unit;

- efficiency drive motor of the i-th pump unit;

- efficiency transmission (with a direct rigid connection of the electric motor to the pump, which, basically, takes place in the pumping units of the machine water lifting system, $=1$ ).

Current efficiency value the pump, taking into account the cavitation-abrasive wear of its working bodies, can be determined by the expression [1]:

$\eta_{H A i}$ - the efficiency of the i-th pumping unit as part of the pumping system;

$\eta_{i}$ - efficiency of the pump of the i-th pump unit;

$\eta_{д в . i}$ - efficiency of the drive motor of the i-th pump unit;

$\eta_{\Pi . i}$ - efficiency of the transmission (with a direct rigid connection of the electric motor to the pump which basically takes place in the pumping units of the machine water lifting system, $\eta_{\Pi=1}$ ).

Current efficiency value of the pump, while taking into account the cavitation-abrasive wear of its working bodies, can be determined by the expression [1]:

$$
\eta_{i}=K_{\text {ИзН }} \cdot \eta
$$

where $K_{\text {изН }}$ - the wear factor of the pump working bodies, calculated as

$$
K_{\text {ИзН }}=\mathrm{e}^{-0,00000833^{*} \mathrm{~T}} \text { пр ; }
$$

$\eta$ - efficiency of the pump determined for each specific operating conditions of the pumping unit.

Efficiency value the pump of the drive motor, taking into account its load, can be determined by the formula [4]

\footnotetext{
* Corresponding author: abidoff@ rambler.ru
} 


$$
\eta_{д В . i}=\frac{1}{1+\left(1 / \eta_{д B . t}-1\right) \cdot\left(K_{Z . i}+A_{\Pi} / K_{Z . i}\right) /\left(1+A_{I}\right)}
$$

where

$$
K_{Z . i}=\frac{1}{K_{\text {ИзН }} \cdot K t} \cdot \frac{P_{M . i}}{P_{Д B . H}},
$$

$K t$ - coefficient that takes into account the change in the rated power of the electric motor depending on the ambient temperature (t0), which is determined in accordance with the following expression:

$$
K t=1,24-0,000196 \cdot t_{0}^{2}
$$

The combination of the above formulas makes it possible to calculate by expression (1) the specific consumption of electrical energy of each of the pumping units, combined for joint operation into a common hydraulic pressure network, as part of a pumping unit. The specific flow rate of the pumping unit of machine water lifting systems as a whole can be determined as:

$$
\Delta_{\ni=2,724 /} \eta_{H y}, \mathrm{~kW} \cdot \mathrm{h} / 1 \mathrm{mln} \cdot \mathrm{m}^{3} \cdot \mathrm{m},
$$

где $\eta_{H у}$ - efficiency of the pumping unit.

It is known [6] that, for example, the overall efficiency of a pumping unit, structurally consisting of two different types of pumping units operating in parallel, can be determined as:

$$
\eta_{H Y}=\frac{\left(Q_{1}+Q_{2}\right) \cdot \eta_{H A .1} \cdot \eta_{H A .2}}{Q_{1} \cdot \eta_{H A .2}+Q_{2} \cdot \eta_{H A .1}}
$$

$Q_{1}, Q_{2}$-feed (flow) of the first and second pumping units respectively;

$\eta_{H A .1}, \eta_{H A .2}$ - efficiency of first and second pumping units respectively.

In a similar way, an expression can be obtained for any other number of operating pumping units, structurally united for joint parallel operation into a common pressure network.

$$
\eta_{H Y}=\frac{\sum_{i=1}^{N} Q_{i}}{\sum_{i=1}^{N} \frac{Q_{i}}{\eta_{H A . i}},}
$$

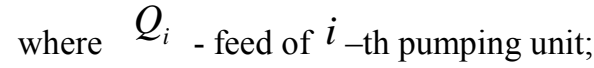

$\eta_{\text {HA.i }}$ - efficiency of $i_{- \text {th pumping unit; }}$

$N$ - quantity of operating pumping units in the system

Thus, the relations obtained on the basis of (9) which make it possible to calculate the efficiency pumping unit, depending on the number of jointly functioning pumping units, as well as taking into account equations [7], which determine the corresponding performance characteristics of the pumps and (1), (4) for efficiency pump and drive motor of each of the pumping unit together with the constraints determine the analytical mathematical model of the pumping unit.

\section{Research results and discussion}

Of these constraints, a more detailed consideration is required to determine the form of the equation for finding the operating point of the pumping units, located on the characteristic of the pressure network, which undoubtedly has one of the defining values in describing the technological process of water supply of the pumping unit. The position of the operating point of the "pumping unit - pressure network" system corresponds to its material and energy equilibrium and is characterized by the well-known hydraulic equation that determines the required pressure of the pipeline network [8]:

$$
H_{T P}=H_{C T}+h_{V}+h_{k}+h_{P}+h_{o n s},
$$

where

$h_{V}$ - head loss in the suction pipeline of pumping units;
$h_{k}$ - head loss in the communication pipeline of pumping units;

$h_{P}$ - head loss in the supply pressure pipeline of pumping units;

$h_{\text {ons }}$ - head loss in the general hydraulic pressure network of the pumping unit.

To determine losses in pressure pipelines of pumping stations of machine water lifting systems, one should use a number of known hydraulic relationships and reference data [6], as well as the results of experimental studies conducted by F.A. Shevelev [7].

The head loss in the suction pipeline of a pumping unit can be determined by the expression:

$h_{V . i}=R_{V . i} * Q_{i}^{2}$.

Suction line resistance $R_{V . i}$ calculated as:

$R_{V . i}=K_{\text {ПоП.i }} * A_{\text {УД. }} * L_{V . i}$,

where

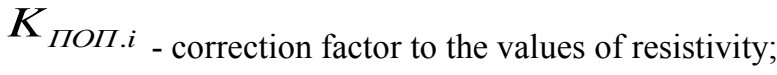

$A_{\text {УД.і }}$-steel pipe resistivity $i_{-}$th pump unit;

$L_{V . i}$ - suction pipe length $i_{-}$th pump unit.

The correction factor is in accordance with the formula:

$K_{\text {ПоП. } i}=0,8144 * \vartheta_{i}^{-0,0884}$,

13)

where

$\vartheta_{i}$ - speed of water movement in the pipeline ${ }^{i}$ - th pump unit, which is defined as:

$$
\vartheta_{i}=Q_{i} /\left[0,785 *\left(\mathrm{D}_{\mathrm{vi}} / 1000\right)^{2}\right] \text {, }
$$

where

$\mathrm{D}_{\mathrm{vi}}$ - inner diameter of the suction line $i_{-}$th pump unit. The specific resistance of a steel pipeline is calculated by the expression: 
$A_{\text {УД. } i}=0,001478 /\left(\mathrm{D}_{\mathrm{vi}} / 1000\right)^{5,226}$.

Head loss in communication pipeline $i_{-}$th pump unit is defined as:

$$
\begin{aligned}
& h_{k . i}=R_{k . i} * Q_{i}^{2} ; \\
& R_{k . i}=K_{M} * K_{\text {ПОП. } i} * A_{\text {УД. } . i} * L_{k . i},
\end{aligned}
$$

where

$R_{k . i}$ - pressure head communication line resistance $i_{- \text {th }}$ pump unit;

$K_{M}$ - coefficient that takes into account pressure losses in local resistances (gate valve, check valve, places of smooth turning, gradual expansion or narrowing, etc.) of pressure pipelines;

$L_{k . i}$ - length of pressure communication pipeline $i_{-}$th pump unit.

For this type of discharge line $A_{\text {УД.і },}, K_{\text {ПОП.і }}$ are calculated by formulas (15) and (13), respectively, using the size (in $\mathrm{mm}$ ) of the inner diameter of the communication pipeline Dki.

Due to the complexity of the hydraulic phenomena occurring in the pressure pipelines of the pumping station of machine water lifting systems, each local resistance is characterized by its own loss factor, which is usually determined empirically or, in some cases, can be calculated from theoretical data. Wherein $K_{M}$, for each specific pumping unit of machine water lifting systems, taking into account the design of the entire complex of the pipeline pressure network, bearing in mind the presence of certain types (types) of local resistances, which, as a rule, are determined from special reference literature $[6,7,8]$. Head loss in the supply pressure pipeline $i_{-}$th pump unit is calculated in the same way as above using the formula:

$$
\begin{aligned}
& h_{P . i}=R_{P . i} * Q_{i}^{2} \\
& R_{P . i}=K_{M} * K_{\text {ПОП. } . i} * A_{\text {УД. }} * L_{P . i},
\end{aligned}
$$

where

$R_{P . i}$ - pressure supply line resistance $i_{-}$th pump unit;

$L_{P . i}$ - length of the supply pressure line $i_{-}$th pump unit. For the considered type of design of the pressure pipeline $K_{\text {ПОП.і }}$ and $A_{\text {УД.і }}$ are calculated in the same way by formulas (13) and (15) taking into account the size of the inner diameter of the supply pressure pipeline $\mathrm{D}_{\mathrm{pi}}$.

Based on the ratios obtained above, the averaged total head losses in the pipelines of the pumping unit of machine water lifting systems to their point of connection to the common pressure network is determined by the expression:

$$
h_{\Sigma S}=\frac{\sum_{i=1}^{N}\left(h_{V, i}+h_{k, i}+h_{P, i}\right)}{N}=\frac{Q_{H N}^{2}}{N} * \sum_{i=1}^{N}\left(R_{V, i}+R_{k, i}+R_{P, i}\right) .
$$

Provided that all pumping units are equipped with the same type and identical hydraulic power equipment with the appropriate characteristics, the total head loss $h_{\Sigma S}$ can be expressed through the flow rate $Q_{T}$ pumping unit in the following form:

$$
h_{\Sigma S}=\frac{1}{N^{3}} * Q_{T}^{2} * \sum_{i=1}^{N}\left(R_{V \cdot i}+R_{k . i}+R_{P . i}\right)
$$

The head loss in the general hydraulic pressure network of the pumping unit of the machine water lifting systems is expressed by the equation:

$h_{\text {ons }}=R_{\hat{\imath} \hat{a}} * Q_{T}^{2}$,

где

$R_{\text {об }}=K_{M}+K_{\text {ПОП }}+A_{\text {уд }}+L_{\text {об }}$

$R_{\text {об }}$ - resistance of the common pressure network of the pumping unit of the machine water lifting systems;

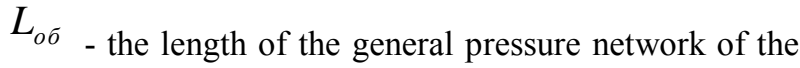
pumping unit of the machine water lifting systems.

When a pumping unit of machine water lifting systems is operating, the operating point of its operation is determined by the total flow rate-pressure characteristic of the pumping unit and the characteristic of the pipeline hydraulic pressure network in accordance with the equality $H_{T}=H_{T P}$. This means that at a given operating point, the pressure developed by the pumping unit of machine water lifting systems is equal to the pressure required by the pipeline network in order to ensure the required supply. Therefore, the equation of the regime point, taken into account in the constraints (10), will take the form:

$$
H_{T}=H_{C T}+\left[R_{o б}+\frac{1}{N^{3}} * \sum_{i=1}^{n}\left(R_{V . i}+R_{k . i}+R_{P . i}\right)\right] * Q_{T}^{2}
$$

\section{Conclusion}

Thus, all the necessary analytical expressions required for the formation of a mathematical model of a pumping unit for machine water lifting systems have been determined in the form of the dependence of the specific consumption of electrical energy on the design, operational and technological parameters of its functioning, which allow to optimize and study the operating modes of the pumping unit to ensure energy-resource saving of the system machine water lifting.

\section{References}

1. Kamalov TS, Khamudkhanov MM, Akhmedov I. Guidelines for standardizing the specific rates of electrical energy consumption and forecasting energy consumption by pumping stations, cascades of pumping stations, wells and by planning levels. Tashkent: Uzinformenergo, 1990 .-- 79 p.

2. Karelin V.Ya., Minaev A.V. Pumps and pumping stations. -M .: Stroyizdat, 1986.-320 s.

3. Turk V.I., Minaev A.V., Karelin V.Ya. Pumps and pumping stations. -M .: Kolos, 1977.-297 p. 
4. Khamudkhanov M.M., Khamudkhanov M.M. On the question of determining the norms of electricity consumption of pumping stations operating on a closed irrigation network // Abstracts of the reports. All-Union Scientific and Practical. Conf., -Tashkent, 1993.S. 205.

5. Andreev V.P., Sabinin Yu.A. Basics of the electric drive. M.-L .: State Energy Publishing House, 1963. $772 \mathrm{p}$.

6. Rychagov V.V., Florinsky M.M. Pumps and pumping stations. Moscow: Kolos, 1975.416 p.

7. Khamudkhanov M.M., Khamudkhanov M.M. Yopik sugorish tarmogi pump kurulmasining mathematician modelini tuzish // Murakkab zharayonlarni va objectlarni modelllashtirish hamda boshkarish. ToshDTU Ilmiy Makolalar Tuplami, -Toshkent, 1994.28-29 b.

8. Palishkin N.A. Hydraulics and agricultural water supply. -M .: Agropromizdat, 1990.-351 s.

9. Kurganov A.M., Fedorov N.F. Handbook on hydraulic calculations of water supply and sewerage systems. 3rd ed. -L .: Stroyizdat, 1986.-384 p.

10. Shevelev F.A. Tables for hydraulic calculation of steel, cast iron, asbestos-cement and plastic pipes. -M $\therefore$ Stroyizdat, 1986. -114 p.

11. Vilner Ya.M., Kovalev Ya.T., Nekrasov B.B. A reference manual for hydraulics, pumps and hydraulic transmissions. -Minsk: Higher school, 1985. -384 p.

12. Zakirov G.Sh., Ayupov R.Kh. Algorithmization of constructing mathematical models of continuous technological processes. -Tashkent: FAN, 1986.-105 p.

13. Kamalov T.S., Khamudkhanov M.M., Khamudkhanov M.M. Algorithmic and software support of energy-saving modes of operation of pumping stations of a closed irrigation network // Problems of energy saving and efficiency of the region's economy. Abstracts of reports. All-Union Scientific and Practical. Conf., -Leningrad, 1990.S. 76-77.

14. Abidov K.G., Khamudkhanova N.B. Mathematical model of a pumping unit for systems of water-lifting pumping stations. Electrical equipment: operation and repair. Russia. \# 1. 2021, pp. 27-32.

15. Khamudkhanov M.M. Rational use of water and energy resources by improving the operating modes of pumping units connected in parallel // Efficiency of using resources in improving the management of production, technological processes and equipment. Part 1. Abstracts of reports. revp. scientific and practical conf. TashPI, Tashkent, 1988.S. 156.

16. Moiseev N.N., Ivanilov Yu.P., Stolyarova E.M. Optimization methods. -M .: Nauka, 1978.-352p.

17. Abidov K, Zaripov O.O. Analysis of self-starting modes of pumping motors. -TEST. Engineering and Management, March - April 2020. ISSN: 0193-4120 Page No. 1785 - 1789. (АҚШ).

18. Abidov K, Zaripov O.O. Automatic drive-support method for constant pressure maintanence at pump units of the hydraulic power stations. - E3S.Web of Conferences 216, 01110 (2020) RSES 2020.
19. Abidov, K., Zaripov, O., Zaripova, S. Automatic drive -support method for constant pressure maintanence at pump units of the hydraulic power stations. E3S Web of Conferences, 2020, 216, 01110.

20. Abidov, K., Zaripov, O. Self-starting of pump units when extinguishing voltage in the energy saving mode. E3S Web of Conferences, 2019, 139, 01088. doi: $10.1051 / \mathrm{e} 3$ sconf/201913901088

21. Sevinov, J.U., Zaripov, O.O., Zaripova, Sh.O.: The Algorithm of Adaptive Estimation In The Synthesis of The Dynamic Objects Control Systems. Inter. J. of Adv. Science and Techn., 29(5s), 1096-1100 (2020). http://sersc.org/journals/index.php/IJAST/article/vie w/7887.

22. Igamberdiyev, H.Z., Yusupbekov, A.N., Zaripov, O.O., Sevinov, J.U.: Algorithms of adaptive identification of uncertain operated objects in dynamical models. Procedia Computer Science. 120, 854-861 (2017). DOI: 10.1016/j.procs.2017.11.318. 